\title{
Grażyna LegutKo
}

(Uniwersytet Jana Kochanowskiego w Kielcach)

\section{Od mrocznego labiryntu do „pustyni miasta" Obrazy ulic w prozie Andrzeja Struga}

\author{
Rzeczywistość jest nieprzejrzysta, \\ bezsensowna sama w sobie, \\ nie ma do przekazania żadnych znaczeń, \\ dopóki my jej tychże znaczeń nie nadamy².
}

\section{Prolegomena}

Tytułowa formuła szkicu wskazuje dwie figury myślowe, między którymi rozciąga się szereg rozmaitych metafor przestrzennych występujących w prozie Andrzeja Struga. Do najczęstszych w interpretowanych przeze mnie utworach należą: labirynt, podziemie, miasto-potwór, nagi bruk, biała kraina śmierci, przeklęta pustynia, rozpasany Babilon, trakt bez duszy i wyrazu, pustynia miasta. Kompozycja tytułu pokazuje też charakterystyczny kierunek ruchu (myśli/działania) bohaterów - od zamknięcia do otwarcia - i sugeruje pewien proces: od kluczenia-ucieczki przez śmierć (fizyczną i mentalną) do odrodzenia.

Wybór analizowanych dzieł - a będą to opowiadania z cyklu Ludzie podziemni (1907-1909) oraz trzy powieści: Dzieje jednego pocisku (1910), Chimera (1918), Pokolenie Marka Świdy (1925) - motywowany jest ich podobieństwem tematyczno-kompozycyjnym. Wszystkie wpisują się, choć

1 A. Strug, Wigilie, [w:] tenże, Ludzie podziemni [seria pierwsza, 1908], Warszawa 1957, s. 90. Wszystkie cytaty pochodzą z tego wydania, dalej w nawiasach stosuję skrót: Lp I, po nim bezpośrednio podaję numer strony, z której pochodzi przytoczenie.

2 J. Kociatkiewicz, M. Kostera, Antropologia pustych przestrzeni, [w:] Pisanie miasta-czytanie miasta, red. A. Zeidler-Janiszewska, Poznań 1997, s. 76. 
w różnych zakresach, w tradycję prozy quasi-biograficznej ${ }^{3}$, a także w nurt ideologiczny literatury młodopolskiej, reprezentujący służebny (związany z polityką historyczną) model sztuki. Zbliża je problematyka rewolucyjno-niepodległościowa i sposób kreacji postaci, które - mimo różnic pokoleniowych, socjalnych i intelektualnych - są zaangażowane w realizację idei społeczno-politycznej (biorą czynny udział w działalności rewolucyjnej bądź służą ",polskiej Sprawie”) albo przynajmniej wykazują chęć takiego zaangażowania. Wątki ideologiczne w omawianych tekstach ściśle korespondują z opisem życia wewnętrznego bohaterów, wysuniętym w narracji na plan pierwszy. Ludzi podziemnych łączy z Dziejami jednego pocisku, prócz tematyki rewolucyjnej, fragmentaryczność struktury fabularnej - zarówno powieść o „dziejach pocisku”, złożona przez twórcę w jedną całość z czternastu krótkich, pierwotnie autonomicznych utworów prozą, jak i zbiór nowel o "ludziach podziemnych"4 redukuje całościowy obraz życia bohaterów do niewielkich wycinków czasowych, zdeterminowanych autentycznymi wydarzeniami historycznymi. W Chimerze i Pokoleniu Marka Świdy jest inaczej - narracja zmierza do prezentacji pełnej biografii protagonistów, odsłaniając proces ich dojrzewania. Obaj w momencie rozpoczęcia akcji znajdują się „na życiowym zakręcie”, poszukują sensu własnej egzystencji. Sytuacja inicjalna implikuje dalszy rozwój zdarzeń, układających się w ciąg przyczynowo-skutkowy, kończący się uzyskaniem przez bohaterów samowiedzy. Pokolenie Marka Świdy stanowi swoistą kontynuację Chimery - dzieje Przecława Borszowskiego puentuje decyzja wstąpienia do Legionów Piłsudskiego (tuż przed wybuchem Wielkiej Wojny), Marka Świdy otwiera moment rozpoczęcia studiów w Krakowie, gdzie sceptycznie obserwuje strzelców musztrujących się na Błoniach (1913 r.). Zachowaniami obu mężczyzn rządzi opozycja: słowo-czyn (pasywizm-aktywizm), obaj też reprezentują typ artysty-improduktywa, usiłując z miernym skutkiem realizować swoje pasje literackie: Przecław zamierza napisać rozprawę o dziejach duszy polskiej („,syntezę psychiki pokoleń porozbiorowych" ${ }^{5}$ ), Marek - wielką powieść o Polsce („obraz tego, co jest w nas, wokoło nas, za nami, przed nami"6).

3 Ludzie podziemni to szereg minibiografii konspiratorów lub osób pośrednio związanych z ruchem socjalistycznym, Dzieje jednego pocisku obejmują pełną historię życia-wędrówki bomby (od narodzin do śmierci), Chimera i Pokolenie Marka Świdy skupiają się na prezentacji indywidualnych losów protagonistów.

4 Mam na myśli trzy kolejne serie cyklu: I. Ludzie podziemni (1908), II. Z pamiętnika starego sympatyka (1907-1908), III. W twardej stużbie (1909).

5 A. Strug, Chimera, Warszawa 1918, s. 17. Wszystkie cytaty w szkicu pochodzą z tego wydania powieści, dalej w nawiasach stosuję skrót: C.

6 A. Strug, Pokolenie Marka Świdy, Warszawa 1958, s. 275. Dalsze cytaty z powieści za tym wydaniem z użyciem skrótu: P. 
Wybrane przeze mnie utwory wiąże również charakterystyczny sposób kreacji przestrzeni miejskiej. W silnie spsychologizowanej twórczości Struga jest ona z reguły zawłaszczona przez emocje i doświadczenia postaci, uzależniona od ich duchowego wnętrza, jaźni bądź podświadomości. Obrazy ulic są funkcjonalizowane introspektywnie przez percypującą świadomość bohaterów, zsynchronizowane z ich aktualnym stanem psychicznym i poddane subiektywnej waloryzacji. Nawet jeśli pojawia się opis ujawniający perspektywę auktorialną (wykazujący tendencję do odnarracyjnej obiektywizacji), to współgra on z punktem widzenia postaci ${ }^{7}$. Przestrzeń miejska w prozie autora Chimery jest zazwyczaj silnie osadzona $\mathrm{w}$ realiach topograficznych, ale zabiegi twórcy związane $\mathrm{z}$ konkretyzacją miejsca niewiele mają wspólnego z praktyką artystyczną pisarzy realistycznych. Przywoływane - najczęściej w strumieniu narracji personalnej - nazwy rzeczywiście istniejących obiektów, ulic czy dzielnic (obok dat i odwołań do autentycznych wydarzeń historycznych) odnoszą świat wykreowanych zdarzeń do geograficznych miejsc i ich powszechnie rozpoznawalnych detali - np. w Warszawie są to: Zamek Królewski, Cytadela, Nowy Świat, Stare Miasto, Marszałkowska, Wola, Powiśle; w Krakowie: Wawel, Sukiennice, kościół Mariacki, kopiec Kościuszki, Błonia; w Łodzi: Piotrkowska, Widzew, Bałuty; w Paryżu: wieża Eiffla, Łuk Triumfalny, Luwr, Notre Dame, Montmartre, Montparnasse, Lasek Buloński. Nazwy te jednak nie tyle służą uprawdopodobnieniu fikcji literackiej, ile stanowią pretekst (czy punkt wyjścia) do zabiegu interioryzacji przestrzeni zewnętrznej, która nigdy nie jest biernym tłem akcji, tworzącym jedynie koloryt lokalny fabuły. Ale rzadko też występuje na prawach całkowitej autonomii - istnieje z reguły ze względu na psychiczne dyspozycje bohatera prowadzącego, staje się współczynnikiem jego emocjonalnych reakcji i procesów myślowych. Uwewnętrznienie obrazu świata - przyczyniające się do liryzacji prozy autora Nekrologu - zmierza zatem w kierunku

\footnotetext{
7 Przykładem może być chociażby opis Zamku Królewskiego w Warszawie w Dziejach jednego pocisku. Nie służy on konkretyzacji miejsca akcji ani też realistycznemu opisowi walorów architektonicznych zabytkowej budowli, ale jest pretekstem do formułowania refleksji historiozoficznych dotyczących przeszłości narodu i mentalności współczesnych Polaków. Zabieg animizacji („,ponuro patrzy na Wisłę, a przez Wisłę na szeroki kraj pusty") paradoksalnie podkreśla metaforyczną śmierć obiektu. Jest „martwy, urzędowy, splugawiony wiekową nieustająca przemoca, która tam założyła sobie koszary". Kojarzy się przede wszystkim z brakiem wolności i znienawidzoną władzą zaborczą rezyduje w nim bowiem samowładny generał gubernator rosyjski: „pies psów carskich”, , , dozorca i kat". A zatem obiektywna prezentacja Zamku bliska jest horyzontowi i odczuciom zniewolonych mieszkańców Warszawy, a zwłaszcza konspiratorom spiskującym przeciwko rosyjskiej okupacji. Cytaty pochodzą z: A. Strug, Dzieje jednego pocisku, Warszawa 1957, s. 31 i s. 34. Dalsze przytoczenia z powieści za tym wydaniem z użyciem skrótu: D.
} 
pogłębionej penetracji psychiki kreowanych postaci i wydobycia najistotniejszych rysów ich osobowości.

Bohaterowie Struga rzadko oglądają miasto z zewnątrz i z oddali, np. $\mathrm{z}$ perspektywy natury wiejskiej czy z dystansu turysty ${ }^{8}$. Z reguły eksplorują miejską rzeczywistość od wewnątrz, z perspektywy ulicy, chodnika, placu, bram, zaułków i przede wszystkim przez pryzmat - powtórzmy to raz jeszcze - indywidualnej jaźni. Personalny horyzont narracji wpływa na stałe przenikanie się dwóch płaszczyzn: wewnętrznej (subiektywne obrazy wytwarzane w wyobraźni postaci) i zewnętrznej (prawdopodobnej, pozornie tylko istniejącej obiektywnie), przy czym podmiotowe widzenie przestrzeni nie jest bezrefleksyjną obserwacją. Bohaterowie Struga to głównie osoby introwertyczne: małomówni konspiratorzy, nerwowo wyczerpani „ludzie podziemni”, nadwrażliwi rozbitkowie porewolucyjni, rozczarowani wolnością mieszkańcy niepodległej Polski. Poza obsesyjnymi skłonnościami do autoanalizy objawiają właściwości neurasteniczne, czasem wręcz patologiczne (rozdwojenie jaźni), nieustannie balansują na granicy dwóch rzeczywistości ${ }^{9}$. Nie dziwi więc, że charakterystyczną cechą wielu opisów przestrzeni jest jej ekspresjonistyczna deformacja ${ }^{10} \mathrm{i}$ fragmentaryzacja, wiążące się z psychiczną dezintegracją (rozbiciem osobowości). Wpływa ona często na niemożność intelektualnego ogarnięcia zarówno świata zewnętrznego, jak wewnętrznego oraz poczucie braku globalnego sensu. Dodatkową komplikację stanowi problem nakładania się pamięci przeszłości na aktualne stany psychiczne bohaterów - wspomnienia, kojarzące się im z danym miejscem, zakłócają klarowny odbiór rzeczywistości widzianej tu i teraz.

Rozmaite punkty widzenia przestrzeni miejskiej nie prowadzą jednak do polifonicznego kształtu świata przedstawionego w prozie Struga ${ }^{11}$,

8 Perspektywiczne (całościowe) ujęcia miasta w prozie Struga funkcjonują na zasadzie wyjątku i są to najczęściej opisy miast obcych, np. amerykańskiej aglomeracji portowej w Dziejach jednego pocisku czy Paryża w Chimerze.

9 Często granica między snem a jawą (świadomościa/halucynacją) ulega zatarciu. Zdaniem S. Kryńskiego zjawisko to bliskie jest „filozoficznym koncepcjom Bergsona (»rzeczywistość pojęta jako nieustanny przepływ bezpośrednich doznań, nie dających się ani od siebie oddzielić, ani myślowo uogólnić«), stanowiącym ontologiczne i poznawcze uzasadnienie ekspresjonizmu" - tenże, Wizja rewolucji we wczesnej prozie Andrzeja Struga (1902-1912), Rzeszów 1989, s. 107.

${ }^{10}$ Opisy przestrzeni osadzone w poetyce ekspresjonistycznej korzystają - jak na prozę modernistyczną przystało - z osiągnięć młodopolskiego impresjonizmu i symbolizmu.

${ }^{11}$ Jak słusznie zauważa B. Pięczka: „proza Andrzeja Struga pozbawiona jest aspektu »wielogłosowości«. Rozpisana na "głosy « poszczególnych bohaterów, rzeczywistość przedstawiona $\mathrm{w}$ tej prozie jest $\mathrm{w}$ istocie podporządkowana perspektywie auktorialnej, za którą kryje się utajona obecność autora" - tenże, Proza narracyjna Andrzeja Struga, Wrocław 1987, s. 244. 
przeciwnie: jego wymiar jest uzależniony od konkretnych uwarunkowań historycznych (decydujących o określonych rozstrzygnięciach pisarza) i w ich kontekście ma jednorodny (homofoniczny) obraz - inny w okresie rewolucji (odpowiadający figurom: labiryntu, miasta-potwora, nagiego bruku, białej krainy śmierci), inny w czasach porewolucyjnych (pojawiaja się znamienne metafory: bezdusznej pustki, jałowej pustyni i rozpasanego Babilonu), jeszcze inny w latach powojennych (dominuje figura pustyni miasta oraz traktu bez duszy i wyrazu). Uwarunkowania historyczne wpływają z kolei na „pejzaż psychiczny” postaci, który determinuje odbiór ulicznego krajobrazu.

\section{Pokręcony labirynt ciemnych ulic}

Tytuł cyklu opowiadań Ludzie podziemni - mających na celu ukazanie dramatycznych epizodów z okresu rewolucji 1905 r. i czasów bezpośrednio ją poprzedzających - wskazuje znamienne terytorium spiskowej działalności "ludzi-kretów", „ludzi-cieni”. Jest nim symboliczne po d zi e mi i ${ }^{12}$ miasta - sfera duszna, mroczna, zamknięta. Przebywanie w niej wiąże się z naturalną tęsknotą do zwyczajnej egzystencji, do zacisza i ciepła domowego ogniska. Tęsknotę tę „ludzie podziemni" heroicznie w sobie tłumia, ich bunt wobec niesprawiedliwości społecznej zakłada wszak niezłomność, zgodę na status bezdomności, ciągłe ukrywanie się przed szpiclami, niespokojne życie „bez wypoczynku”.

Przymusowa wędrówka konspiratorów wiedzie przez przecinające się ulice, kluczące trakty, zawiłe arterie, niespodziewane przecznice, nagle urywające się szlaki, ślepe zaułki itd. Przypomina błądzenie po mieście, kojarzące się w sposób oczywisty z motywem labiryntu ${ }^{13}$. Mimo wewnętrznego chaosu, komplikacji i zamknięcia, przestrzeń ta jest u Struga miejscem oswojonym i w gruncie rzeczy spiskowcom przyjaznym, umożliwia bowiem ucieczkę, uwolnienie się od nadzoru. Łatwo w niej zgubić tropy, zatrzeć ślady. Dramatycznie pogmatwana topografia miasta, stanowiąca metaforę złożonego, pełnego napięć życia wewnętrznego rewolucjonistów, w pierwszej kolejności kojarzy się więc w prozie Struga z miejscem azylu. Dzieje się tak w debiutanckim Nekrologu, gdzie upersonifikowane „kąty, dziury i zaułki warszawskie" (Lp I, 8) tęsknią do obecności zmarłego działacza, pytają o los bliskiego im „człowieka spod ziemi”, czy w Wigiliach, gdzie

\footnotetext{
${ }^{12}$ Wszystkie podkreślenia w szkicu pochodzą od jego Autorki.

${ }^{13} \mathrm{O}$ wyjątkowej nośności tego motywu pisał M. Głowiński w szkicu Labirynt. Przestrzeń obcości, [w:] tenże, Mity przebrane. Dionizos. Narcyz. Prometeusz. Marchott. Labirynt, Kraków 1990, s. 129-216.
} 
ulica Młynarska odbierana jest przez Tańskiego jako „kąt boży”, w którym można się schronić i „nie potrzeba się zbytecznie krępować ani zanadto oglądać. Szpicle nie zapuszczają się w tę mroczną szyję" (Lp I, 42).

Ale bywa też odwrotnie. Przestrzeń miejska opisywana jest jako wroga, obca, zła. Najwyraźniej eksponują to Cienie. Bohater noweli, cierpiący na manię prześladowczą (dręczy go widmo-zmora wszechobecnego szpiega), ucieka w popłochu przez „nieskończony labirynt ulic" ${ }^{14}$. Ulice jawią mu się jako: dalekie, obce, nieznane, puste, nieprzyjazne. Tytułową obsesję komentuje i jednocześnie puentuje tragiczny finał utworu: przestrzeń wokół ściganego zamyka się, „rozsiane po całym świecie cienie, wśród których przemykał się" (Lp III, 38) tworzą obławę, zagradzając wszystkie drogi. Podobna wizja osaczenia pojawia się w Sielance. Znajdujący się na letniej kuracji za miastem, wyczerpany konspiracją i postępująca gruźlica, Stanisław Krzemski ze wstrętem wspomina pełne wrzawy, kurzu, brudu i zaduchu ulice Warszawy, którymi musiał nieustannie kluczyć. Wielkoprzemysłowa aglomeracja - skontrastowana $\mathrm{z}$ arkadyjskim pejzażem wsi - kojarzy się bohaterowi z "potwornym wielkomiejskim piecem” (LP III, 61), obezwładniającym zmęczonych, spracowanych ludzi, wtrącającym ich umysły w bezmyślną bydlęcość. Antyurbanistyczna projekcja wzmocniona zostaje w innych utworach Struga motywem „zawartych bram” lub "muru kamienic", dookreślanym charakterystycznymi epitetami: nieprzerwany, zimny, nieprzystępny, wysoki, zbity, nienawistny, nieskończony, ślepy itp. Wizja nieprzyjaznej, zamykającej się przestrzeni, miasta-klatki, miasta-więzienia, staje się zatem antytezą azylu, bezpiecznego „kąta bożego". Owo przeciwstawne postrzeganie przestrzeni miejskiej wynika, rzecz jasna, z uczuciowej i intelektualnej ambiwalencji „ludzi podziemnych", z ich skomplikowanego - jak labirynt - wnętrza, którego sami nie pojmują i nie ogarniają.

$\mathrm{Z}$ reguły ulica „ludzi podziemnych" to ulica widziana noca, w półmroku, w mętnym świetle latarni bądź tonąca w nieprzeniknionych ciemnościach. Ulica opustoszała lub pustoszejąca, cicha lub niema, uśpiona lub zasypiająca. Jej nieodłącznymi atrybutami - prócz wszechobecnych szpicli, wpływających na permanentne poczucie zagrożenia i zaszczucia, są dziury w chodnikach, mroczne załamki, wyboiste kamienie, ciemne zaułki, tajemne kąty, wysokie parkany, wąskie bramy, czarne czeluście, ciasne szpary, szczeliny między murami, uchylone furtki, wyrwy w murze, zasłonięte okna domów, zapleśniałe sutereny, walące się podstrysza. Te ostatnie, będące czytelną ikoną ubóstwa najbiedniejszych

${ }^{14}$ A. Strug, Cienie, [w:] tenże, W twardej stużbie [Ludzi podziemnych - seria trzecia], Warszawa 1957, s. 36. Wszystkie cytaty z tej serii pochodzą z tego wydania, dalej w nawiasach zastosowano skrót: Lp III. 
mieszkańców, budzą rozmaite emocje rewolucjonistów - od współczucia, rozpaczy i totalnej bezradności, przez konstruktywny bunt, do obrzydzenia, poczucia winy, zdrady, wreszcie obojętnej apatii. I tak ciemna, błotnista, zatłoczona ulica - pełna niezliczonej ilości dzieci, siedzących po rynsztokach, tarzających się w kurzu lub grzebiących w śmieciach - urasta w percepcji Krzemskiego do symbolu „przeokropnej nędzy życia” (Lp III, 62) i upodlenia człowieka; zmusza go do autorefleksji, wywołuje iście judymowe dylematy. Kontemplacji krzywdy wielkomiejskiego proletariatu i powinności społecznych wobec niego towarzyszą zwątpienie i bunt, a zarazem poczucie wstydu:

Ponury tragizm bił od tej ulicy. Niepowstrzymane obrzydzenie, bunt okropny wybuchał w uspołecznionej duszy Krzemskiego. Niewolnicy - niewolnicy na wieki wieczne - kto ich obudzi, kto zdoła im wytłumaczyć ohydę ich życia? Kto ich namówi, by poczuli krzywdę swoją by poznali krzywdziciela i po swoją krwawą własność rękę wyciągnęli?

Takie obrazy obezwładniały jego wolę hartowaną od lat całych. Beznadziejny smutek spadał nań i zatapiał wszelką myśl, wszelkie pragnienie. Po co? Na co? (Lp III, 61-62)

Na podobne wyróżniki ulicy warszawskiej zwraca uwagę Tański - bohater Wigilii. Kłują go w oczy słabo oświetlone sklepiki „podobne do nor", gnieżdżące w sobie „robactwo ludzkie” (Lp I, 41), nędzne parterowe zabudowania, koszlawe drewniaki, ciasne stancyjki. Kryjąc się przed szpiclowską obławą w ślepych zaułkach i klucząc w nieprzeniknionych ciemnościach miejskich traktów, słyszy nagle zza przymkniętej okiennicy sutereny pod ziemią „głuchy dźwięk młotka szewskiego i widzi: śpieszy się suchotniczy niewolnik” (Lp I, 89), innym razem wzrusza go napotkana niespodziewanie w ciemnym kącie "skulona postać bezdomnego nędzarza, zatulonego w przemokły gałgan” (tamże).

Los nędzarzy śpiących na ulicy jest alegorią losu „ludzi podziemnych”, również pozbawionych własnego domu i możliwości spokojnego snu. Przeciwstawiony im zostaje filisterski tłum mieszczan, sytych i zadowolonych z siebie, śpiących twardo za szczelnie zamkniętymi okiennicami. Ale ulica w opowiadaniach Struga to nie tylko przytułek ubogich, to także schronienie dla głęboko skrywanych myśli rewolucjonistów, niemy partner dialogu, sprzyjający stawianiu trudnych pytań i rozwiązywaniu problemów. Z relacją tego rodzaju mamy do czynienia w noweli Z ręki przyjaciela, koncentrującej się na dylematach Walerka, nie mogącego zrozumieć, dlaczego o zdradę został oskarżony przyjaciel, który wyciągnął go z alkoholizmu i wskazał cel w życiu. Bohatera wędrującego samotnie w niewiadomym kierunku po pustych ulicach śpiącej Warszawy dręczą wątpliwości; podważa on zasadność oskarżenia, pyta o przyczyny apostazji - niestety: „Głucho odzywa się chodnik. Milczy ulica” (Lp I, 129). 
Ulica bywa też niekiedy tożsama ze sferą sacrum, zwłaszcza gdy staje się poligonem demonstracji robotniczych, jak to ma miejsce w finale późnego opowiadania Ze wspomnień starego sympatyka, gdzie widzimy typową dla literatury młodopolskiej, zbliżonej ideologicznie do PPS, tendencję do mitologizacji ruchu - bruk placu Grzybowskiego w projekcji „starego sympatyka" przeobraża się w święte miejsce narodzin „nowych ludzi”, ich „krwawego chrztu" ${ }^{15}$. Największe zagęszczenie motywów ulicznych znajdujemy jednak w dużo wcześniejszych Wigiliach. Klamrę kompozycyjną utworu stanowią informacje czasowo-przestrzenne: dziejąca się w Warszawie akcja rozpoczyna się po dziesiątej wieczór, kiedy Tański wychodzi „z bramy domu na ulicy Młynarskiej” (Lp I, 41), kończy zaś o przedświcie przy ponurym murze Pawiaka, do którego dociera po całonocnej włóczędze-ucieczce śmiertelnie znużony bohater. Na obraz dzielnic Warszawy, po których kluczył (mrocznych zakamarków Śródmieścia, ślepych zaułków Powiśla, ciasnych przesmyków Woli), i konkretnych ulic, które przemierzał $^{16}$, nakłada się siatka znaczeń subiektywnych; rzeczywistość zewnętrzna jest impresyjnie transformowana w obręb życia wewnętrznego Tańskiego. Jego aktualny stan psychofizyczny (rozdrażnienie, senność, ogólne wycienczenie organizmu) powoduje, że widzi przed sobą miasto piętrzące się , ,jak potworna, ciemna góra" (Lp I, 50). Charakterystyczny jest moment, kiedy zauważa na Chmielnej czteropiętrową kamienicę, wyglądającą jak „ponury pomnik na cmentarzu pamiątek" (Lp I, 64). W rozchwianej wyczerpaniem fizycznym wyobraźni bohatera potężny gmach ulega animizacji: patrzy nań „setką zimnych ciemnych okien" (LP I, 63), a następnie uruchamia ciąg wspomnień o: srogim ojcu i łagodnej matce, dorastaniu na Powiślu, brataniu się z bandami andrusów i złodziei, kontaktach z socjalistami, fascynacji nową ideologia, początkach konspiracji, wreszcie o więzieniu w X Pawilonie Cytadeli. Kamienica znajduje się bowiem na gruzach rodzinnego domu Tańskiego. Rozpamiętywanie prywatnych dziejów wywołuje tęsknotę za czasem bezpowrotnie minionym i rodzi pytanie o sens idei mi ej sca: „Miejsce - pojęcie matematyczne czy filozoficzne, czy jakie..." (tamże).

Pogłębione refleksje natury społecznej wyzwala z kolei u Tańskiego inny obiekt, przy którym zatrzymuje się w czasie nocnego błądzenia

\footnotetext{
${ }^{15}$ A. Strug, Ze wspomnień starego sympatyka [opowiadanie tytułowe; Ludzi podziemnych - seria druga], Warszawa 1957, s. 202. Wszystkie cytaty z tej serii pochodzą z tego wydania, dalej w nawiasach stosuję skrót: Lp II.

${ }^{16}$ Skrupulatne przywoływanie nazw ulic, po których wędruje Tański (Młynarska, Wolska, Krochmalna, Nowy Świat, Karolkowa, Wróbla, Ordynacka, Aleksandria, Tamka, Dobra, Solec, Radna, Lipowa, Oboźna, Topiel, Karowa, Podwale, Krakowskie Przedmieście, Trębacka, Chmielna, Towarowa, Niska, Śliska, Nowolipie i in.), umożliwia nie tylko obiektywną lokalizację opisywanych miejsc, lecz uzmysławia także, jak niebotyczne odległości musiał pieszo pokonać bohater.
} 
„W pokręconym labiryncie ciemnych ulic” (Lp I, 89). Jest nim fabryka Bormanna. Przyglądając się czerwonym murom olbrzymiej budowli, snuje rozważania na temat zgubnych skutków rozwoju cywilizacji przemysłowej, alienacji pracy i zawiłych dziejów socjalizmu. Jego zmęczona myśl ożywia martwą fabrykę - przeobraża ją w potwora, Molocha „sytego krwi i ofiar"17, złego boga panującego nad niewolnikami (ludźmi-maszynami), to znów w boga nienasyconego, żądnego żertwy ofiarnej. W rozgorączkowanej, półprzytomnej imaginacji bohatera wstrętny i nienawistny gmach ulega dalszym transformacjom - wydaje mu się, że „szydzi zeń milczeniem swoim i natrząsa się z wysiłków człowieka" (Lp I, 75). Koszmarny omam rodzi zwątpienie w sens jakiegokolwiek działania i dotkliwe poczucie samotności. Tański czuje się jak tropione i zaszczute zwierzę, osaczone przez miasto-potwora ${ }^{18}$. W finale opowiadania, w pobliżu znajomych murów Pawiaka, dokonuje się wszak symboliczne oczyszczenie myśli bohatera - wyzwala się z dręczących go omamó $\mathrm{w}^{19} \mathrm{i}$ odzyskuje wiarę $\mathrm{w}$ sens walki, konieczność czynu w zastępstwie i w imieniu towarzyszy śpiących za więzienną kratą.

Przywoływana już kilkakrotnie figura labiryntu w Wigiliach ma różne konotacje. Odpowiada sytuacji kluczenia, uwikłania, zapętlenia, osaczenia, ale jednocześnie jest przestrzenią bohaterowi przychylną, paradoksalnie otwartą (ulice prowadzą w nieskończoną dal), tożsamą w końcu z jego nocnym schronieniem, bezpiecznym portem, miejscem, gdzie może się przespać. Labirynt jest również odpowiednikiem błądzenia „w pustkowiu myśli własnych" (Lp I, 89) oraz symbolicznym miejscem ideowego przebudzenia. Metaforyczne wyjście $\mathrm{z}$ „labiryntu myśli" stanowi złożenie obietnicy anonimowemu nędzarzowi, śpiącemu „gdzieś w zaułku Nowolipia, w kącie między wpół rozwaloną ruderą a na wpół wymurowaną kamienicą" (tamże):

${ }^{17}$ Antropomorficzna wizja fabryki-potwora była wówczas powszechnie znana nie tylko z prozy E. Zoli, ale także z odwołującej się do tropów naturalistycznych literatury młodopolskiej, by przywołać tylko Ziemię obiecana W.S. Reymonta czy Próchno W. Berenta.

${ }_{18} \mathrm{O}$ popularnym motywie miasta-potwora, pojawiającym się już w romantyzmie, a spopularyzowanym przez H. Balzaka, traktuje m.in. szkic C. Miłosza Legenda miasta-potwora, [w:] tenże, Legendy nowoczesności. Eseje okupacyjne, Kraków 1996, s. 18-34. O młodopolskiej realizacji tego motywu pisała I. Maciejewska w studium Wielkie miasto w prozie okresu Młodej Polski a problemy naturalizmu, [w:] Problemy literatury polskiej okresu pozytywizmu, seria III, red. E. Jankowski i J. Kulczycka-Saloni, Wrocław 1984, s. 197-222.

${ }^{19}$ Rozmyślania Tańskiego przy murze Pawiaka S. Kryński określa mianem „modlitwy przy grobie, mającej charakter »wypominków « przyjaciół, zmarłych i tych, którzy jeszcze żyją (na wolności lub w więzieniu)" i interpretuje jako „egzekwie Struga nad wczorajszymi dziejami", nabożeństwo żałobne, kojarzące się ze smutkiem, ale też wiarą w zmartwychwstanie, dodajmy: wiarą w pozagrobowe zwycięstwo rewolucji. Tenże, dz. cyt., s. 38-39. 
- Słuchaj! Nie będzie wnuk twój spał na ulicy, jak pies bezdomny! Ja ci to mówię! Ty zginiesz, jako i ja zginę, ale my już ostatni, wierzaj, jako i ja wierzę, który ci to powiadam w tej nocnej godzinie...

Teraz ciche i kojące uczucie zrozumienia prowadziło go dalej przez pustynię miasta. (Lp I, 90)

„Uczucie zrozumienia” powoduje, że zamknięta przestrzeń labiryntu otwiera się. Znamienne, że o świcie Tański patrzy w opancerzone w blachy okna Pawiaka „jak w okna własnego domu” (Lp I, 92). Wykładnia znaczeniowa labiryntu ma zatem, jak widać, w prozie Struga charakter co najmniej ambiwalentny, i z pewnością nie jest jedynie „przestrzenią obcości", by uciec się do kwalifikacji, jakie mu przypisał Michał Głowiński²0.

\section{Nagi bruk i biała kraina śmierci}

Równie charakterystycznym jak labirynt znakiem rozpoznawczym ulic Struga jest bruk. Motyw ten najobficiej występuje w Dziejach jednego pocisku i kojarzy się w sposób oczywisty z wymową ideową głośnej noweli Żeromskiego Nagi bruk (1906), której tytuł wskazuje dosłowną i symboliczną zarazem przestrzeń. W finale utworu - tuż przed pojawieniem się w poprzecznym zaułku uzbrojonego oddziału żandarmerii rosyjskiej - ulica pogrąża się w przerażającej ciszy-pustce, od „nagich ścian” domów odcinają się „,zamknięte okna, zatrzaśnięte drzwi i nagi bruk. Nagi bruk..."21. Dumny i nielękający się śmierci tłum demonstrantów - spośród którego wyróżnia się postać oberwanego szewca i kobiety podtrzymującej jedną ręką sztandar, a drugą unoszącej w górę swe niemowlę - zrasta się w ,jedną bryłę” i idzie po nagim bruku „niezachwiany, wyniosły, ślepy i głuchy", jak „,̇̇y w y pocisk, torujący drogę wolności" 22 .

Dzieje jednego pocisku rozpoczynają z kolei znamiennie zdania:

Długo ten owoc dojrzewał... Wlokły się lata, gubiąc życie i trawiąc dusze w ludziach. Biła we wroga Idea i Nienawiść, wielu ludzi poświęcenie i cierpliwie w męce czekanie. [...] Aż któregośdnia potoczył się po bruku pocisk dynamitowy. (D 5)

Dystans czasowy (powieść ukazała się kilka lat po klęsce rewolucji) wpływa na inny niż w pisanych na gorąco opowiadaniach Struga obraz ulicy i odmienny status „ludzi podziemnych”. Wychodzą

\footnotetext{
${ }^{20}$ Zob. M. Głowiński, dz. cyt.

${ }^{21}$ S. Żeromski, Nagi bruk, [w:] tenże, Pisma zebrane, red. Z. Goliński, t. 4: Sen o szpadzie. Pomyłki i inne utwory epickie, oprac. Z.J. Adamczyk, Warszawa 1990, s. 48.

${ }^{22}$ Tamże, s. 47.
} 
wreszcie na powierzchnię - ich "podziemne” bytowanie osiągnęło kres i cel. Przywołajmy raz jeszcze Nagi bruk Żeromskiego, tym razem jego początek:

R o zw a rła się wielka brama... Z głębi murów olbrzymich, zadymionych sadza, wyszedł na ulicę wielki ludzki tłum. Wyszedł od razu, wywalił się jak bryła. Powiewała nad nim czerwona chorągiew, płótno we krwi zmaczane ${ }^{23}$.

Bruk u Struga, podobnie jak u Żeromskiego, jest ekwiwalentem przestrzeni otwartej, na którą wydostał się z „pokręconego labiryntu ciemnych ulic" człowiek pod-ziemny. To czytelna metafora losu rewolucjonistów, określenie ich kondycji, symbol aktywizmu, jawnego działania, walki wprost. Szorstki, kamienny bruk jest nagi jak: obnażony (bezbronny) jest samotny "człowiek podziemny", stojący na przegranej pozycji wobec silniejszego wroga; daleki od wykwintności - skromny, zwyczajny, odheroizowany; pozbawiony gorsetu konwencji-naturalny, szczery, ujawniający swoje zamiary. W Dziejach jednego pocisku nagi bruk jest również symbolicznym miejscem narodzin "dynamitowego pocisku”, początkiem jego nad-ziemnego lotu, areną rewolucji. W sensie dosłownym to miejsce, z którego można przyglądać się pracy tajnej drukarni, jak to robi zafascynowany towarzysz Weszycki, i po którym przebiegają hałaśliwie "chłopaki - roznosiciele gazet" (D 228). Ale to także przestrzeń zagrożenia, w której słychać niepokojący tętent kopyt oddziału konnej żandarmerii, wzbudzający lęk w Kamie, idącej z bombą wzdłuż mrocznej, ponurej, pustej ulicy, obramowanej parkanami i drucianymi płotami. To teren węszących szpicli, ulicznych rewizji i policyjnych patroli. To wyboista droga do Cytadeli, którą pędzone są pod konwojem gromadki zdekonspirowanych działaczy. To wreszcie miejsce śmierci "ludzi podziemnych" - „rycerzy nocy”, ,"machin do ciskania bomb” (D 56) - oraz demonstrujących proletariuszy („Raz po raz, jak niesforne dzieci, wypadały tłumy robotnicze na ulicę, wyzywając carat, i po salwach zostawały na bruku trupy - trupy - trupy", D 94). I choć kształt miejskiego bruku jest w Dziejach jednego pocisku uzależniony od punktów widzenia różnych postaci, przez co jego obraz pulsuje wieloznacznością w gruncie rzeczy jest jednorodny, spaja go bowiem motyw śmierci ${ }^{24}$. Przyjrzyjmy się uważniej tej jedności w wielości.

${ }^{23}$ Tamże, s. 44.

${ }^{24}$ O motywie śmierci w Dziejach jednego pocisku - w sposób oczywisty łączącym się z tematem rewolucji (śmierć jest wszak ontologicznie wpisana w istotę każdej rewolty zbrojnej) - pisałam w artykule Rewolucyjny lot ku śmierci. „Dzieje jednego pocisku” Andrzeja Struga a "Jaskótka" Gustawa Daniłowskiego, [w:] Andrzej Strug, red. K. Stępnik i M. Gabryś, Lublin 2011, s. 187-198. 
W porównaniu z cyklem Ludzie podziemni opis przestrzeni miejskiej w powieści o "dziejach pocisku” jest geograficznie bardziej urozmaicony - poza Warszawą znajdujemy w niej deskrypcje ulic trzech wielkich miast: Łodzi, Krakowa i aglomeracji portowej w Ameryce. Ta ostatnia zwłaszcza wiąże się z poczuciem samotności w tłumie, tak charakterystycznym dla bohaterów Struga. Ilustruje je postawa byłego więźnia Cytadeli, anarchisty Gryziaka, który z perspektywy olbrzymiego mostu, zawieszonego wysoko nad odnogą oceanu, z niechęcią obserwuje „poczwarne kadłuby trzydziestopiętrowych kamienic” (D 166), tonące $\mathrm{w}$ dymach kominy fabryczne, ciągnące się bez granic szklane hale i dachy biurowców, nieskończone sznury świateł ulicznych, „bielące się martwym połyskiem niezliczone okna domów-wież” oraz „roje wielkich napisów z ognia, obwieszczające światu kolosalnymi literami panowanie pieniądza" (D 167). Mityczny kraj wielkich zarobków i dobrobytu wydaje mu się z gruntu obcy, okropny i okrutny, czuje totalną alienację wśród milionów zajętych sobą ludzi, którzy intensyfikują jego opuszczenie, bezdomność i egzystencjalne zagubienie. Nie dziwi więc, że po powrocie do Polski, wędrując bez celu warszawskimi ulicami, odbiera je jako radosny azyl, przestrzeń niczym nieskrępowanej wolności (,zgiełk uliczny, łoskot dorożek i wozów odurzał go i napawał szczęściem. Chciało mu się śpiewać, śmiać i dużo gadać" - D 164). Żądny przygód, z rozmysłem szuka na ulicy zaczepki - stanowi ona dlań swoiste wyzwanie, poligon brawurowych czynów. Wykolejony moralnie, bez namysłu i skrupułów morduje ludzi. Z czasem jednak coraz dotkliwiej odczuwa wokół siebie pustkę i to na ulicy właśnie uświadamia sobie jałowość własnego życia i jego nieogarnioną nicość. Prowokacyjnie strzela do rosyjskich żołnierzy patrolujących ulicę, z bezradną rozpaczą wystawiając się na śmierć.

Ulica-wyzwanie to także pokusa nerwowego inteligenta - psychiatry, w którego mieszkaniu przez jakiś czas ukryty jest pocisk. Ciekawy procesów psychicznych „zachodzących w duszach bojowców, ocierających się codziennie o śmierć" (D 17), z premedytacją przechadza się tam i z powrotem Marszałkowska, mając przewieszony przez ramię futerał $\mathrm{z}$ bombą i wyzywająco zaglądając w oczy policjantom. Podobne podniecenie wzbudza myśl o ulicy w rosyjskim generale gubernatorze, który neurotycznie ukrywa się przed zamachowcami w Zamku Królewskim (percypowanym jako martwa klatka-więzienie) i tęskni do tętniącego życiem ruchu miejskiego, choćby chwilowego zaznania wolności między spacerującymi beztrosko mieszkańcami stolicy. Obsesyjnie marzy o wyjściu z „więzienia” 25

\footnotetext{
${ }^{25} \mathrm{O}$ archetypie więzienia będącego syntezą wszelkiej zamkniętej przestrzeni por. studium E. Goffmana, Charakterystyka instytucji totalnych, tłum. Z. Zwoliński, [w:] Elementy teorii
} 
na otwartą przestrzeń, strach przed śmiercią okazuje się ostatecznie od marzeń silniejszy.

Myślenie rosyjskiego dygnitarza o ulicy łączy dwie jej skrajne jakości, często wskazywane przez innych bohaterów powieści - jest strefą nieograniczonej wolności i miejscem budzącym paniczny lęk. Podobnie odbiera ulicę towarzyszka Kama. Oglądając z perspektywy dorożki zatłoczone, pełne zgiełku ulice Pragi, jest nimi jednocześnie zaciekawiona i przerażona. Nie pojmuje tego, co wokół siebie widzi. Wyobraża sobie, że jedzie w jakiś „obcy świat, zaludniony przez twory o niepojętych, tajemniczych przeznaczeniach, między istoty niechybnie skazane na coś strasznego" i czuje "bliski oddech czyjeś niechybnej śmierci” (D 16). Kiedy zaś idzie z bomba, by dokonać zamachu na wroga, wpada w stan nienaturalnej euforii, który powoduje, że postrzega ulicę jako przestrzeń pogodnej zabawy, wolności, radosnego gwaru karnawałowych kramów. Kroczy po bruku wesoło, z dumnie zadarta głową, odczuwa irracjonalne szczęście. Po niedoszłym zamachu wraca do swego poprzedniego nastroju, pogrąża się w apatii, „martwym bezwładzie, ponurym, grobowym smutku" (D 49); ulica staje się znów sferą obca, przygnębia ją i zarazem trwoży potworną zwyczajnością, rychło zaczyna ją dręczyć jak koszmarny sen.

Wielkomiejska ulica budzi jeszcze większe przerażenie w starej włókniarce z Łodzi, wycieńczonej wieloletnią nędzą Cywikowej. Niepokojąc się o los syna rewolucjonisty, przypomina sobie pierwsze wrażenie, jakie wywarło na niej ogromne miasto, w momencie gdy przybyła do niego ze wsi jako mała dziewczynka. Ciekawy wzrok dziecka, spoglądającego z perspektywy sutereny na ulice „bawełnianego królestwa”, zarejestrował wówczas znamienne szczegóły:

Naokoło wszyscy obcy, źli, nieużyci, a domy takie ogromne, a miasto takie ogromne, a tyle ludzi, aż za dużo. Bała się mała wszystkiego, a najbardziej strasznych, dymiących kominów, które sterczały wszędzie, gdzie było spojrzeć, i podpierały niebo. Przerażały ją swoim ogromem i tą cudownością, że się nie przewracały, i dymem, i krwawą czerwoną barwą. Kiedy na nie patrzyła, przypominały jej się najstraszniejsze miejsca z bajek o złych duchach i to, co o piekle opowiadał ksiądz proboszcz dla zastraszenia grzesznych ludzi wiejskich. (D 86)

Ikona miasta-piekła to figura losu starej Cywikowej. Wzmacnia ją zaprezentowana $\mathrm{w}$ narracji auktorialnej infernalna wizja świata przyszłości, pogrążającego się w ogniu zniszczenia i rozlewającego się rzekami czerwonymi od krwi. Łódzka wdowa tuż przed aresztowaniem jedynego syna

socjologicznych. Materiaty do dziejów współczesnej socjologii zachodniej, red. W. Derczyński, A. Jasińska-Kania, J. Szacki, Warszawa 1975, s. 150-177. 
i swoją własną śmiercią, czuje się jak nagi kamień w bruku ulicznym, na którym wybudowano wielkie gmachy:

Ona, jak ka mień węg i elny, jest wmurowana w fundament gmachów fabrycznych, banków, pałaców, kościołów. Na niej wznosi się potęga państw, szczęście rodzinne, cnoty kulturalne i wszelki postęp, i wszelkie piękno. Jest twarda jak skała [...], ale gdzieś tam, na dnie dusz czy w głębi ziemi, istnieje jej n a g i e, jak prawda, okropne i niepojęte jądro. (D 88)

Ulica w Dziejach jednego pocisku to zatem nie tylko element konkretnej topografii miejskiej, percypowany subiektywnie przez bohaterów i korespondujący z ich aktualnym stanem psychicznym, to także przestrzeń wyobrażona. Centralnym elementem fantazyjnych projekcji, będących wytworem obłąkanych myśli postaci, jest najczęściej śmierć (czyjaś lub własna). I tak na przykład psychiatra, który snuje maniackie refleksje na temat śmierci, widzi pośrodku mrocznej i pustej ulicy zabitą Kamę - leżącą w błocie i sponiewieraną. Ona sama chodzi nieprzytomna po warszawskim bazarze, jakby to były Pola Elizejskie. Najbardziej spektakularną wizję generuje jednak wyobraźnia Kamila, absolwenta uniwersytetu, do pewnego momentu (jak Kama) bezgranicznie oddanego Sprawie. Rozczarowanie klęską rewolucji, nasilająca się nerwica, poczucie bezsensu życia sprawiaja, że konkretne ulice Krakowa, które ogląda przez olbrzymie okna kawiarni, przekształcają się $\mathrm{w}$ jego wyobraźni w jakieś odrealnione formy. Zamiast rynku i rojących się na nim ludzi widzi przed sobą tajemnicza, pustą i zimną równinę, przypominającą niezmierzoną matematycznie równą białą płaszczyznę, w której pogrąża swe myśli:

Życie można spędzić idąc ku jej granicom - nie ma końca biały świat. Nie ma na nim drogi, kierunku. Ani śladu żywej istoty. Martwo i głucho. [...] Nie ma do kogo uciec. Nie ma dokąd. Ta przestrzeń pochłania każdy wysiłek. Nie ma ona granic, jest wieczna. [...] Step lodowy. Pusto, równo, przeraźliwie. Tęskno, strasznie, samotno... [...]. Uśmiechnął się do swojej tajemnicy. Już ją odgadł. To śmierć. Jego śmierć. Jakże kochać należy dobra, białą pustynię! Jak trzeba błogosławić jej martwe pola spokoju, zapomnienia! [...] Kamil spoglądał w swoją białą krainę. Na ustach jego ukazał się lekki uśmiech i pozostał. (D 232-235)

Wizja białej krainy śmierci ${ }^{26}$ jest ostatnią rzecza, jaką jest w stanie wyobrazić sobie duchowo spustoszony, wypalony, wewnętrznie martwy, ostatecznie zmarnowany dla Sprawy rewolucjonista.

\footnotetext{
${ }^{26}$ Podkreślić tu należy znamienną cechę poetyki Struga, jaką jest dążność do alegoryzowanej prezentacji świata psychicznego bohaterów. Zwracają na to m.in. uwagę K. i K. Kłosińscy w artykule Proza Struga: między modernizmem a dwudziestoleciem. Próba interpretacji, [w:] Proza Andrzeja Struga. Studia, red. T. Bujnicki i S. Gębala, Warszawa 1981, s. 17.
} 


\section{Przeklęta pustynia i rozpasany Babilon}

W zbliżonej do Kamila kondycji psychicznej znajduje się cierpiący na „porewolucyjną neurastenię” (C 17) główny bohater Chimery, powieści będącej studium aktualnych problemów nękających Polaków w kraju pozbawionym państwowości. Sekwencja scen z "warszawskiego życia” Przecława Borszowskiego stanowi zbiór luźno zespolonych sytuacji, który odpowiada rozbiciu i zagubieniu ideowemu protagonisty, niepotrafiącego po rozłamie w partii i upadku rewolucji odnaleźć swego miejsca wśród zwalczających się stronnictw politycznych. Obraz ulic Warszawy, po których się snuje bez konkretnego celu i z poczuciem egzystencjalnej pustki, odbywając nałogowo codzienne wędrówki po mieście, jest zdeterminowany jego permanentną melancholią. Razi go miałki gwar uliczny i wesoły ruch przechodniów; przygnębia "opuszczony bruk Warszawy” (C 20) niepamiętający o niedawnej walce; uderza ogólna jałowość miejskiej przestrzeni. Subiektywna waloryzacja Borszowskiego koresponduje z ironiczną oceną sporów partyjnych między działaczami PPS-Frakcją i PPS-Lewicą.

Prezentowana w Chimerze ulica warszawska - w przeciwieństwie do jej opisów w Ludziach podziemnych i Dziejach jednego pocisku - jest bowiem przede wszystkim miejscem dyskusji ideologicznych, przestrzenią sło wa (bezpłodnych teorii), nie czynu (konstruktywnego działania). To na niej Borszowski toczy maniackie dysputy polityczne z przypadkowo spotkanymi znajomymi. Ich czczość wkrótce go wszak zniechęca - poddaje się stagnacji, wewnętrznemu letargowi, zupełnie oddala od życia publicznego. Brzydzi go życie Warszawy zapustnej, karnawałowej, w której od frontu ulic jaśnieją jaskrawym światłem okna burdeli, a na wystawach sklepowych eksponowane są carskie portrety. Wybucha złością, słysząc na ulicy dźwięki „,kacapskiego dzwonienia z cerkiewki” (C 84) i obserwując haniebne galówki. Nie może pogodzić się z postępującym zruszczeniem polskich ulic, irytują go sterczące na nich dniem i nocą:

[...] jak słupy, typy pokraczne, z grubsza ciosane i ociężałe w sutych czapach obcego kroju, w nadziegciowanych buciarach, przy kolosalnych do śmieszności szabliskach - typy, które pozornie pochłonięte były jeno utrzymaniem ładu wśród nieposkromionych dorożkarzy warszawskich. (C 40)

Ugodowa postawa mieszkańców stolicy („niewolniczych typów, od urodzenia upodlonych" - C 59) budzi w nim nieprzezwyciężony wstręt. Czuje wściekłość wobec powszechnej zgody na "oficjalny gwałt” (C 84) najeźdźcy i nienawiść wobec ulicznego tłumu: zadowolonego z siebie, biernego, pokornego, splugawionego i znikczemniałego. Denerwuja go filisterskie twarze przechodniów - zrównoważonych otyłych panów, 
przyzwoitych ojców rodzin, władców życia, dbających o pełną kieszeń i spokój domowego stadła. Z rzadka tylko zdarzają mu się momenty innego widzenia, kiedy czuje pod powierzchnią bezmyślnego tłumu jakieś „,podziemne drgnienie zatajonej duszy" (C 82) i słyszy jakąś „straszliwą skargę życia" (C 83). Pogłębiająca się z czasem depresja Borszowskiego, warunkowana emocjonalną pustką i ogólną frustracją powoduje, że Warszawa staje się dlań „przeklętą pustynią”, w której zaczyna się dusić. Wreszcie utraciwszy wiarę w cokolwiek, postanawia porzucić „przeklęte ulice skalanego grodu" (C 88) i wyjechać do Paryża.

Notowane z realistyczną dokładnością szczegóły miejskiej topografii stolicy nad Sekwaną (białe mury bazyliki Sacré Coeur, wyniosłość Montmartre'u, mroczny Panteon, oazy parku Luksemburskiego i parku Monceau, cmentarz Montparnasse, zieleń Lasku Bulońskiego, złota kopuła Inwalidów, potężne masywy Notre Dame, majestatyczny Luwr, imponujący Łuk Triumfalny, Pałac Sztuki, Trocadero, „wbite, jak pal w obraz miasta, żelazne dziwadło Eiffla" - C 154) podporządkowane są, rzecz jasna, stanowi emocjonalnemu przybysza i z nim synchronizują:

Całą istotą swoją czuł Przecław pełnię szczęścia. [...] odgadywał każdą tajemnicę miasta, zrastał się z jego murami, wcielał się w jego ludzi. Był w zmowie z duszą Paryża, z jego opiekuńczym geniuszem. Niepostrzeżenie, wśród zachwytu nieopatrznie wyszedł z siebie, poza siebie. Myślał tak, jak gdyby był rodzonym synem tego miasta. (C 152-153)

Przeżycia wewnętrzne bohatera sprawiaja że obraz Paryża ulega interioryzacji, zostaje wkomponowany w jego indywidualną świadomość. W młodopolskiej wyobraźni Przecława (jest wszak artystą) przekształca się w miasto-świat, starożytny Babilon, odwieczne miejsce szatańskiej rozpusty i grzechu ${ }^{27}$. Mimo iż określa go mianem „potwornego ludzkiego mrowiska" (C 143), jest oczarowany czy wręcz opętany jego nieskończonym ogromem, nieodgadnioną potęgą myśli, uwodzicielską tajemniczością, ustawicznym ruchem i nie dającą się uchwycić zmiennością. W swej egzaltowanej imaginacji dokonuje stereotypowej personifikacji przestrzeni paryskiej:

Coraz to innym głosem, coraz inną myśl wypowiadało miasto. Uśmiechało się szczęśliwe i lekkie, chmurzyło się, martwiało, jak wymarłe, czyniło się złe, stawało w nieopisanej grozie, jak widmo piekła. [...] Nieraz stroiło się miasto we wszystkie barwy i dźwięczało

${ }^{27}$ Do rozpowszechnienia w Młodej Polsce stereotypu Paryża jako nowożytnego Babilonu przyczynił się przede wszystkim W. Gąsiorowski poprzez swą książkę Babilon (Warszawa 1912). Określenie to wykorzystał F. Ziejka w pracy Nasza rodzina w Europie. Studia $i$ szkice (Kraków 1995) jako tytuł rozdziału: Nowożytny Babilon. Obraz Paryża w literaturze polskiej 1890-1930. Por. też interesujący szkic R. Caillois, Paryż, mit współczesny, tłum. K. Dolatowska, [w:] tenże, Odpowiedzialność i styl, Warszawa 1967, s. 101-120. 
szalonym rytmem radości. Był to ów prawdziwszy od starożytnego Babilon, jedyny ogród rozpasanego grzechu, dokąd po rozkosz zmysłów, po zatracenie i szaleństwo zbiegali się ludzie ze wszystkich krańców świata. (C 144-145)

Paryż - „dziwo świata” - w świadomości Przecława jest przede wszystkim połączeniem bezmiaru przestrzeni i ludzkiej seksualności. Odbywając samotne wędrówki po ulicach „rozpasanego Babilonu”, nie może zaspokoić swojej zachłannej ciekawości, jest nienasycony widoku niepojętej dlań przestrzeni, gubi się w niej myślą. Paryż działa nań terapeutycznie - pozwala zapomnieć o gnębiącej „chimerze polskości”. Borszowski czuje się jak człowiek wypuszczony z więzienia, któremu dane jest zażywać, a nawet „nadużywać słodkiej wolności” (C 151). Zachwyca go radosny gwar ulic, labirynt promenad przypominający zaczarowany las, widok umajonych zielenią kamiennych bulwarów; czuje bliskość wszystkich gmachów, zalanych słońcem murów, kamienic i każdej niezgłębionej czeluści miasta.

Wraz ze zmianą nastroju bohatera obraz Paryża ulega metamorfozie. Poczyna go drażnić „chaos ludzki na rue Richelieu” (C 156), "gmachy, widziane po drodze, wydają mu się jakby nieprawdziwe" (tamże), a samo miasto - „bezlitosne i zdradzieckie na każdym kroku, pełne brzydoty i niecnoty" (C 158). Kiedy indziej, zwiedzając stare dzielnice stolicy nad Sekwaną, wpada w podziw nad nieśmiertelnością i niezniszczalnością narodu francuskiego, jest zafascynowany przeszłością miasta:

Z każdego kamienia, ze wszystkich kątów wyzierały echa wspaniałych i krwawych dziejów narodu. Z kościołów i pałaców, z ciemnych zaułków, z fal Sekwany, z ogrodów i cmentarzy szły ku niemu żywe legendy o tym, co było. Kroku nie mógł stąpić, by nie budzić zamarłych dziejów. Życie dzisiejsze, nowe i inne zapełniało swoim gwarem olbrzymie mauzoleum drogich i strasznych pamiątek. (C 182)

Jego szczególną uwagę przykuwa malownicza Dzielnica Łacińska (nazywana „wyspą umarłych”) z zabytkowym kościołem św. Seweryna. Jej cmentarny smutek wywołuje w bohaterze "chwilowy napad narodowej melancholii" (C 186) i przywołuje dalekie echa polskiego życia. Tłumiona prawda o sobie samym, swojej bezsile, marnowaniu energii, przegraniu, chorobie na polskość - powraca z jeszcze większym natężeniem. Paryż przestaje być bezpiecznym miejscem, chroniącym przed opętaniem własnymi myślami i wewnętrzną walką. W końcu wydaje mu się "dziwnie ciasny":

Wszędzie brudno. Męczyło go wszędy biegające mrowie ludzkie, jego wieczny niepokój i zgiełk. Odmieniło mu się jakoś miasto-świat. Czuł się tu nie jak u siebie, on rozmiłowany w Paryżu, ślubujący jeszcze nie tak dawno pozostać tu na całe życie. (C 224) 
Przebudzenie Borszowskiego do życia w stolicy Francji okazuje się przeto pozornym wyjściem z zapaści. Bohater budzi się bowiem jedynie do życia płytkiego, bezrefleksyjnego, tożsamego z hedonistycznym użyciem. Po powrocie do Polski zgoła inaczej odbiera Warszawę - „syreni gród, płochy i schamiały pod Moskalem" (C 352). Postrzega ją teraz jako "miasto tajemnic", najbardziej fantastyczne miejsce w Europie, kryjące pod powierzchnią zruszczenia, spodlenia, błazeństwa i geszefciarstwa prawdziwie głębokie, wewnętrzne życie.

Drogę poszukiwań ideowych Przecława zwieńcza i zarazem puentuje symboliczny szczyt (przypomnieć warto, że był to pierwotny tytuł Chimery) - miejsce dojścia bohatera: krakowskie Oleandry, skąd wyrusza w szeregach Kadrówki na swój wojenny (pozamiejski już) szlak, by walczyć o wolność ojczyzny. Wraz z optymistycznym finałem powieści kończy się mentalne rozproszenie protagonisty - myślą scalającą jego niezborne do tej pory dylematy staje się „jednocząca idea walki niepodległościowej" ${ }^{28}$.

\section{Trakt bez duszy i wyrazu}

Obraz przestrzeni miejskiej w Pokoleniu Marka Świdy zdeterminowany jest - podobnie jak w utworach wcześniejszych - kondycją psychiczną głównego bohatera i jego postawą życiową. Czas powieściowej akcji jest jednak znacznie rozleglejszy: wydarzenia rozpoczynają się około $1913 \mathrm{r}$. (50-lecie powstania styczniowego), kończą w połowie drugiej dekady XX w. (lata kryzysu ekonomiczno-politycznego II Rzeczpospolitej). W opisach ulic stosowana jest tu konsekwentnie metoda kontrastu, powodująca, że z reguły mamy do czynienia z sąsiadowaniem obrazów przeciwstawnych. Wiąże się to z przyjętą zasadą kreacji protagonisty, zmierzająca do pokazania jego wewnętrznej dysharmonii. Koncepcja psychologiczna postaci opiera się na grze alternatyw, swoistym rytmie iluzji i deziluzji wobec rzeczywistości, a także ambiwalencji stanów duchowych. I tak wymarzony Kraków, w którym pełen energii Marek rozpoczyna studia, rychło odbierany jest przez niego jako przestrzeń martwoty i zamknięcia, jako miasto-grób. Rozczarowany i znudzony młodzieniec, zamiast znaleźć w nim ",skrawek wolnej żywej Polski” (P 35), widzi jedynie zimne mury, przesiąknięte jakąś dziwną melancholią i rezygnacją. W zwiedzanych zabytkach i na ulubionych przez turystów Plantach nie dostrzega najmniejszego śladu życia:

\footnotetext{
${ }^{28}$ Por. K. Woźniakowski, Sprawa robotnicza w prozie polskiej przed rokiem 1918, „Zeszyty Na-
} ukowe Uniwersytetu Jagiellońskiego. Prace Historycznoliterackie" 1980, z. 39, s. 170. 
Kościoły, Wawel, muzea zawierały odmęt pamiątek sprawy umarłej. Tu dopiero dokonał odkrycia, że Polska naprawdę spoczywa w grobie. Opłakana i uczczona leży zamurowana, a nad nią Kraków - Mauzoleum, jedyne miejsce do składania wieńców, narodowych westchnień i łez. (P 35)

Inscenizacja Wesela Wyspiańskiego, którą bohater ogląda w teatrze, inicjuje proces jego narodowej inicjacji i wpływa na radykalną zmianę widzenia miasta. Duszna atmosfera krakowskich ulic w poruszonej wyobraźni studenta przeobraża się w aurę tajemniczej podniosłości. Oglądane miejsca - obdarzone mocą nieśmiertelnego trwania - nabierają charakteru sakralnego:

[...] stanął oczarowany u wylotu ulicy Sławkowskiej. Sukiennice, Panna Maria, Rynek w śniegu i ciszy. Snują się czarne cienie ludzkie, przędą powszedni dzień. Nad nimi stare wieżyce i mury. Niespożyte i odwieczne czekają na ludzi. Za nich czuwają. [...] moc przetrwania czytał Marek jak z proroctwa. Ono wpisane było w stare cegły i kamienie, strzeliste dachy i krawężniki. Uderzyła godzina. Spod pozłocistej korony, spomiędzy rozkwitłych u szczytu gotyckich wieżyczek rozbrzmiał hejnał. Jakowąś myśl-prawdę obwieszczał miastu trębacz od Panny Marii, nieświadom tego, co spełnia. O z w ały się mury [...] ś w i ę te. (P 38-39)

Miasto-życie staje się zatem antytezą miasta-grobu. Nagła chęć dokonania jakiegoś wielkiego czynu tłumi neurasteniczne skłonności Marka i powoduje, że myśli o Krakowie z zachwytem - widzi tajemnicze mgły snujące się pod kopcem, życiodajne słońce oświetlające wieże, czerwone dachy miasta; konstatuje z emfazą: „Zbudziło się, rozwarło oczy ukochane miasto i spojrzało tysiącem zmieszanych barw" (P 43).

Euforia i frenetyczne uniesienie wpływają także na odbiór ulic powojennej Warszawy. Niepodległa stolica robi na Świdzie niesamowite wrażenie - czuje się „niepoczytalnie szczęśliwy, olśniony, opętany" (P 90), zachłyśnięty wolnością. Ze łzami wzruszenia ogląda polskie szyldy i orły państwowe przybite nad drzwiami miejskich urzędów, z nabożeństwem czyta obwieszczenia naklejone na ulicznych słupach. Spaceruje po Warszawie jak "cudownie uleczony ślepiec, który nagle ujrzał świat” (P 91). Niebawem jednak entuzjazm bohatera przekształca się w „radość z odzyskanego śmietnika”, by uciec się do ironicznej formuły Kadena-Bandrowskiego z Generała Barcza. Ta z kolei przemienia się w głębokie rozczarowanie. Tłum uliczny, którego nieposkromiona gadanina nie tak dawno Marka wzruszała, wydaje mu się na powrót pospolity, zwykły, nieciekawy, obcy, zbyt spokojny, tkwiący w jakiejś dziwnej stagnacji. Sama ulica kojarzy mu się z zamętem (będącym odpowiednikiem zamętu politycznego w kraju), którego nie rozumie, podobnie jak nie rozumie samego siebie. 
Obraz warszawskiej ulicy zmienia się zasadniczo w momencie, kiedy Świda snuje refleksje na temat konfliktu polsko-radzieckiego. Konstrukcją opisu rządzi ponownie metoda kontrastu, a także - często stosowana w prozie wojennej - poetyka ekspresjonistyczna. Tuż przed nadejściem armii rosyjskiej na ulicach Warszawy panuje złowroga cisza, są ciemne, puste i wymarłe, przypominają "ciasne, pokrętne, murowane wąwozy" (P 130). Okienne szyby, za którymi spokojnie śpią cywile i w które z zawiścią patrzą żołnierze, są ślepe i martwe. Nagle spokój mieszkańców burzą przegrupowujące się wojska. Ulice stolicy nabierają niecodziennego wyglądu:

Stolica okryła się niezliczoną mnogością odezw, plakatów, podniecających i zachęcających afiszów. Hasła, nakazy, okrzyki, pytania, nawoływania, groźby, maksymy, sentencje, wzniosłe bohomazy, karykatury, dowcipy i szyderstwa nastręczały się wszędzie. Napisy upstrzyły mury, drzewa, tramwaje, słupy, dachy, płoty, szyby, urzędy i lokale, teatry i kościoły. Deptało się po nich na chodnikach, ćmiło się od nich w oczach i głowie. (P 132)

Znamiennym rysem „wojennej” ulicy Warszawy jest jej nieopisany zgiełk i chaos, ale także heroizm. Specyfikę walczących ze sobą narodów podkreśla pojawiający się w narracji auktorialnej opis dwóch kontrastujących ze sobą pod względem architektonicznym budowli. Oto z jednej strony wznosi się na placu Saskim tętniący życiem i nieprzerwanym ruchem gmach sztabu generalnego, z oknami jarzącymi się od światła, z drugiej - majestatyczny, pogrążony w mroku, upersonifikowany gmach soboru: „Od martwej masy kamienia zieje zły urok na wszystko, co tu jest. Z mozaikowego fryzu znad odrzwi »ich « groźny Bóg w sztabie archaniołów ciska przekleństwo wprost w oświetlone okna" (P 135). Ciemność-śmierć carskiego soboru mierzy się zatem ze światłem-życiem Pałacu Saskiego.

Czas powojenny (po zawarciu pokoju w 1921 r.) to w życiu Świdy okres wewnętrznej pustki, beznadziejnego letargu, a zarazem irracjonalnego oczekiwania na wydarzenie się czegoś ważnego, czegoś, co zbudzi go do życia. To czas szczególnego niezadowolenia z siebie, stanu frustracji i depresji nasilającej się pod wpływem traumy demobilizacji. Były oficer - realizujący potrzebę podejmowania wielkich czynów w heroizmie wojennym, sprawdzania siebie w niezwykłych sytuacjach - w cywilu czuje się nikomu niepotrzebny, nie wie, po co ma żyć i co robić; postrzega siebie jako osobę, która nic nie potrafi i do niczego się nie nadaje. Poczucie bezsilności i bezsensu życia rzutuje na percepcję otaczającej przestrzeni. Nic mu się nie podoba: „,wszędzie widzi same dziury, ani śladu zachwytu, nigdzie uroku. Polska jak gdyby mu się nagle zestarzała, zanim zdążył się nią nacieszyć" (P 169). Trakty warszawskie irytują go swoją hałaśliwością i niespokojną ruchliwością, rażą odblaski reklam, mierzi widok „wytrzeszczonych 
wystaw sklepowych" i „tłuszczy wielkomiejskiej mrowiącej się po ulicy" (P 226), ogłusza huk rozpędzonych aut i zgrzytających tramwajów. W „ożywionym tłoku” Świda paradoksalnie odczuwa przeraźliwą pustkę, wiążącą się ze stanem totalnej deprywacji. W konsekwencji nienawidzi miejsca, w którym mieszka:

Marek nie cierpiał Warszawy. Twierdził, że nasza stolica nie ma żadnego charakteru, ani własnego oblicza, ani duszy. Jest to nagie miejsce, gdzie przeszłość zatraciła się i zamarła, a młoda teraźniejszość nie zakorzeniła się jeszcze. (P 226)

Częściową ulgę przynosi mu ucieczka od znienawidzonej rzeczywistości w sztukę (zaczyna pisać), ale rychło ponosi porażkę także na tym polu - załamuje go niemożność wyrazu „tego, co najważniejsze” i niedoskonałość artystyczna. Rozczarowanie twórcze pogłębia depresję i potęguje poczucie otaczającego chaosu. Ulice, które Swida nerwowo przemierza, nie prowadzą w jakimś określonym kierunku - są terenem, gdzie odbywa się bezładny ruch przechodniów:

Sklepy jeszcze otwarte, tłumy ludzi. Płyna śpieszą się, mijają, prześcigają niewyczerpane gromady czarnych postaci. Wszędzie pełno ich niespokojnej krętaniny, spojrzeń, słów, urywków, uśmiechów, gestów. Przebiegają i gina, objawiają się i gasną coraz to nowe ich oblicza, przerozmaite, poosłaniane jednakowo zimna, obojętna, nieprzeniknioną wielkomiejską maską. Jaskrawe światła wystaw sklepowych krają tłum na pasma, każdą postać obleją ostrym blaskiem, odsłonią ją nagle i cisną w zmrok, podadzą ją dalej pod snopy precz czyhających promieni. Ulica mieni się w oczach, drga niepoznawalna i niespokojna. [...] Gapi się ulica, jak urzeczona, w uwielbiającym zapatrzeniu. Nędzna jej zawiść, martwe jest pożądanie pariasów. (P 241)

Opis martwej z natury materii ulicy obfituje w animizacje, potęgujące wrażenie paradoksalnej pustki wokół bohatera. Czuje się „,smutno i samotnie pośród tłumu" (P 242) anonimowych przechodniów, ogłusza go niezrozumiały dlań gwar ludzki, niepojęte, hałaśliwe życie ulicy, które intensyfikuje wewnętrzną martwotę. Nastrój beznadziejnego smutku pogłębia niezadowolenie z sytuacji politycznej w kraju (ciągłe przesilenia gabinetowe, bezsilność rządu), którą obrazują zdesperowani warszawiacy wydzierający sobie na ulicach nadzwyczajne dodatki do gazet oraz „rozpaczliwy ryk samochodów, wzywających ratunku” (P 335), jeżdżących między budynkiem Sejmu na Wiejskiej a gmachem Belwederu.

Dzieje tytułowego bohatera, które można by odnieść do figury pustyni miasta czy traktu bez wyrazu, nie kończą się jednak tragicznie ${ }^{29}$.

\footnotetext{
${ }^{29}$ Nie od rzeczy będzie tu przywołać trafne spostrzeżenie M. Głowińskiego: „Pustka, rozważana w kategoriach abstrakcyjnych, jest w jakimś sensie zaprzeczeniem labiryntu" - tenże, dz. cyt., s. 139.
} 
Modernistyczny pesymizm i fatalistyczny determinizm były wszak światopoglądowi Struga zdecydowanie obce. „Śmiertelnie znużony” bohater nie popełnia samobójstwa, o którym wcześniej myślał, lecz w finale powieści, patrząc w okno księgarni, widzi, że w odbiciu wielkiej szyby „majaczy prawdziwe życie - ulica i ludzie" (P 349), a także twarz ukochanej kobiety. Połączenie tych dwóch odbitych $\mathrm{w}$ oknie-lustrze ${ }^{30}$ obrazów skutkuje zaprojektowaniem w przyszłość idei odrodzeńczej. Idea ta powoduje, że oglądana z balkonu Moniki Goślickiej pusta, cicha, odcięta od miasta ulica warszawska, „zamknięta niewidzialnym zaklęciem” (P 354) i katastroficznie zapadająca się w głąb kamiennego bruku (a zatem przestrzeń m a r t wa) - nagle otwi er a się i ulega procesowi rewitalizacji. Stojący blisko ukochanej Marek słyszy płynący z oddali potężny głos jakiegoś hymnu:

W akordach potężnego śpiewu splątała się wielkość i niedola człowieka w tysiącgłos jego przeznaczenia, w jego żywot, jego śmierć. Długo trwało po nim milczenie. Zapatrzeni w siebie, w zapamiętaniu tej chwili poczynali niewiadomy, nowy swój żywot. W ich duszach wciąż grał hymn na chwałę życia. Od obszaru miasta płynie ku nim zgłuszony i niejasny szmer - pogłos powszedniego dnia, który niesie za sobą wszystko. (P 356)

Trakt bez duszy i wyrazu (vel: pustynia miasta) w percepcji odradzającego się do życia bohatera ulega ostatecznej metamorfozie. Swida przestaje się zmagać wewnętrznie, zaczyna bowiem wreszcie rozumieć (jasno-widzieć) niezgłębioną prawdę, którą kryje w sobie „proste, odwieczne, codzienne by towanie miasta" (P 242), prawdę budzącą wiarę w możliwość lepszej przyszłości, w sens zwyczajnego, codziennego życia. Pojmuje, że w splątanym nurcie tłumów, w mrowisku ulic ukryte są wszystkie tony życia, dźwięczy odwieczna tajemnica ludzkiej egzystencji. By ją dosłyszeć, należy tylko „wytężyć słuch!”.

\footnotetext{
${ }^{30}$ K. Stępnik zauważa: „Lustro i okno w utworach Struga [...] są analogicznie jak sny i wizje kategoriami »widzenia", odsłaniającymi rzeczywistość duchową i psychiczną bohaterów" - tenże, O "Chimerze" Andrzeja Struga, [w:] Andrzej Strug..., s. 53.
} 